\title{
IMPLIKASI DISPENSASI PERKAWINAN TERHADAP EKSISTENSI RUMAH TANGGA DI PENGADILAN AGAMA SEMARANG
}

\author{
Muhammad Kunardi, HM Mawardi Muzamil \\ Dosen Fakultas Hukum Unissula \\ MMuzzamil00@yahoo.com
}

\begin{abstract}
One of the requirements is the age of marriage the bride, the groom reaches the age of 19 years and the woman has reached the age of 16 years. The age limit is to maintain the health of spouses and offspring. If the prospective bride marriage age limit is not sufficient, it must be granted a dispensation from religious court. This marriage dispensation will bring legal consequences for the parties and the implications of the existence of households bride, considering marriage performed by the bride who has not been physically and psychologically mature. The approach used in this study is a socio-juridical. Specifications of this research is descriptive analysis. The results of this study indicate that the arguments raised in the petition in the Religious marriage dispensation Semarang are fears of acts prohibited by religion and the future wife was pregnant. Basic considerations judge in giving marriage dispensation in the Religious Semarang is the provision of Article 7 paragraph (2) of Law No. 1 of 1974. The implications of marriage dispensation in Semarang religious court of the existence of the household is underage marriage causes of conflict in the household lead to divorce, other than that the cause of death in babies born to mothers or because of the lack of physical maturity of the female.
\end{abstract}

Keyword : dispensation, marriage

\begin{abstract}
Abstrak
Salah satu syarat perkawinan yaitu umur kedua mempelai, calon mempelai pria mencapai umur 19 tahun dan pihak wanita sudah mencapai usia 16 tahun. Batasan umur tersebut adalah untuk menjaga kesehatan suami-istri dan keturunan. Apabila calon mempelai belum mencukupi batas umur perkawinan, maka harus mendapat dispensasi dari Pengadilan Agama. Dispensasi perkawinan ini akan membawa akibat hukum bagi para pihak dan implikasi terhadap eksistensi rumah tangga mempelai, mengingat perkawinan dilakukan oleh mempelai yang belum masak secara fisik maupun psikis. Metode pendekatan yang digunakan dalam penelitian ini adalah yuridis sosiologis. Spesifikasi penelitian ini bersifat deskriptif analisis. Hasil penelitian ini menunjukkan bahwa dalil-dalil yang diajukan dalam permohonan dispensasi perkawinan di Pengadilan Agama Semarang adalah kekhawatiran akan terjadi perbuatan yang dilarang oleh agama dan calon istri telah hamil. Dasar pertimbangan hakim dalam memberikan dispensasi perkawinan di Pengadilan Agama Semarang adalah ketentuan Pasal 7 ayat (2) Undang-Undang Nomor 1 Tahun 1974. Implikasi dispensasi perkawinan di Pengadilan Agama Semarang terhadap eksistensi rumah tangga adalah perkawinan di bawah umur penyebab timbulnya konflik dalam rumah tangga yang berujung pada perceraian, selain itu penyebab kematian pada ibu ataupun bayi yang dilahirkan karena belum adanya kematangan fisik pihak perempuan.
\end{abstract}

Kata kunci : Perkawinan, Dispensasi

\section{A. PENDAHULUAN}

Membentuk sebuah rumah tangga yang bahagia dan kekal adalah impian dan dambaan bagi setiap orang. Untuk membentuk keluarga yang sejahtera dan bahagia tersebut, maka diperlukan adanya perkawinan antara seorang laki-laki dan perempuan. Tidak ada sebuah keluarga tanpa adanya perkawinan yang sah 
sesuai dengan norma agama dan tata aturan yang berlaku. Perkawinan tersebut akan menghalalkan hubungan antara seorang lakilaki dan perempuan. Suatu perkawinan yang sah mengakibatkan terjadinya pergaulan lakilaki dan perempuan secara terhormat sesuai dengan kedudukan manusia sebagai makhluk yang berkehormatan. ${ }^{1}$

Perkawinan merupakan perintah Allah S.W.T kepada semua manusia, sebagai bentuk ibadah agar terhindar dari perbuatan maksiat. Allah S.W.T di dalam firman-firman-Nya dijelaskan bahwa manusia telah diciptakan Allah S.W.T berpasang-pasangan yang memungkinkan terjadinya perkembang biakan atau memiliki keturunan, guna melangsungkan kehidupannya, sebagaimana disebutkan dalam Al Qur'an dalam Surat Adz Dzaariyaat ayat 49 yang artinya : "Dan segala sesuatu kami ciptakan berpasang-pasangan supaya kamu mengingat akan kebesaran Allah", dan Surat Ar Ruum ayat 21 yang artinya : "Dan di antara tanda-tanda kekuasaan-Nya ialah Dia menciptakan untukmu istri-istri dari jenismu sendiri, supaya kamu cenderung dan merasa tentram kepadanya, dan dijadikan-Nya di antaramu rasa kasih dan sayang. Sesungguhnya yang demikian itu benar-benar terdapat tanda-tanda bagi kaum yang berfikir".

Dalam Bab I Pasal 1 Undang-Undang Nomor 1 Tahun 1974 dijelaskan bahwa yang dimaksud dengan perkawinan adalah ikatan lahir batin antara seorang pria dengan seorang wanita sebagai suami istri dengan tujuan untuk membentuk keluarga yang sejahtera, kekal berdasarkan Ketuhanan Yang Maha Esa. Dalam perkawinan mempunyai tata cara dan syarat -syarat tertentu yang berbeda-beda di setiap daerah serta harus terpenuhi dalam pelaksanaannya. ${ }^{2}$

Pada Pasal 2 Kompilasi Hukum Islam (KHI) dipertegas landasan filosofis perkawinan sesuai dengan ajaran Islam tanpa mengurangi landasan filosofis perkawinan berdasar Pancasila yang diatur dalam Pasal 1 Undang-Undang Nomor 1 Tahun 1974. Sebagaimana yang dijelaskan dalam Pasal 1 Undang-Undang Nomor 1 Tahun

1 Ahmad Azhari Basyir, 1999, Hukum Perkawinan Islam, UII Press, Yogyakarta, hlm.1.

2 Idris Ramulyo, 1996, Hukum Perkawinan Indonesia, Budi Aksara, Jakarta, hlm. 5.
1974, landasan filosofis perkawinan nasional ialah Pancasila dengan mengkaitkan perkawinan berdasar sila pertama, yakni berdasar Ketuhanan Yang Maha Esa. Landasan filosofis itu dipertegas dan diperluas dalam Pasal 2 Kompilasi Hukum Islam yang intinya berisi : ${ }^{3}$

1. Perkawinan semata-mata untuk mentaati perintah Allah;

2. Melaksanakan perkawinan adalah ibadah;

3. Ikatan perkawinan bersifat miitsaaqan gholidzan.

Sesuai dengan ketentuan Pasal 2 UndangUndang Nomor 1 Tahun 1974 telah diletakkan fundamentum yuridis perkawinan nasional, yaitu:

1. Dilakukan menurut hukum agama; dan

2. Dicatat menurut perundang-undangan yang berlaku.

Dalam Pasal 2 ayat (1) dan ayat (2) UndangUndang Nomor 1 Tahun 1974 Tentang Perkawinan, dinyatakan bahwa :

(1) Perkawinan adalah sah, apabila dilakukan menurut hukum masing-masing agamanya dan kepercayaannya itu.

(2) Tiap-tiap perkawinan dicatat menurut peraturan perundang-undangan yang berlaku.

Pasal 7 ayat (1) dan ayat (2) UndangUndang Nomor 1 Tahun 1974 menyebutkan mengenai batasan umur bagi seorang laki-laki dan perempuan yang akan melangsungkan perkawinan dan upaya yang dapat dilakukan jika terjadi penyimpangan terhadap persyaratan tersebut, yakni :

(1) Perkawinan hanya diizinkan bila piha pria mencapai umur 19 (sembilan belas) tahun dan pihak wanita sudah mencapai usia 16 (enam belas) tahun;

(2) Dalam hal penyimpangan dalam ayat (1) pasal ini dapat minta dispensasi kepada pengadilan atau pejabat lain yang diminta oleh kedua orang tua pihak pria atau pihak wanita.

Penjelasan Pasal 7 ayat (1) Undang-Undang Nomor 1 Tahun 1974 menyebutkan bahwa: "Untuk menjaga kesehatan suami-istri dan keturunan, perlu ditetapkan batas-batas umur

3 M.Yahya Harahap, 2005, Kedudukan Kewenangan dan Acara Peradilan Agama Undang-Undang Nomor 7 Tahun 1989, Sinar Grafika, Jakarta, hlm. 38. 
untuk perkawinan". Di dalam Undang-Undang Nomor 1 Tahun 1974 ini juga menganut prinsip bahwa calon suami istri itu harus telah masak jiwa raganya untuk dapat melangsungkan perkawinan, agar supaya dapat mewujudkan tujuan perkawinan secara baik tanpa berakhir pada perceraian dan mendapat keturunan yang baik dan sehat.

Dispensasi kawin adalah untuk perkawinan yang calon mempelai laki-laki atau perempuannya masih di bawah umur dan belum diperbolehkan untuk menikah sesuai dengan peraturan. Banyak hal yang melatarbelakangi terjadinya perkawinan antara laki-laki dan perempuan yang masih di bawah umur.

Penyebab perkawinan di bawah umur saat ini adalah maraknya pergaulan bebas para remaja yang berujung kehamilan di luar nikah atau yang, akibatnya orang tua cepat-cepat menikahkan anaknya atau yang dikenal dengan married by accident (MBA). Pada kasus ini, masyarakat masih melihat bahwa menikah adalah solusi yang efektif untuk menutup aib yang telah menimpa pada anaknya.

Ketentuan-ketentuan yang mengatur tentang pemberian dispensasi terhadap perkawinan yang berlaku sejak disahkannya Undang-Undang Nomor 1 Tahun 1974 secara lengkap diatur di dalam Peraturan Menteri Agama Nomor 3 Tahun 1975, yaitu :

1. Pasal 12 menitikberatkan kepada dispensasi bagi anak yang belum mencapai umur minimum, yakni :

a. Pernikahan harus didasarkan persetujuan kedua calon mempelai;

b. Seorang calon mempelai yang akan melangsungkan pernikahan belum mencapai umur 21 tahun harus mendapat izin sebagaimana dimaksud Pasal 6 ayat (2), ayat (3), ayat (4), dan ayat (5) Undang-Undang Nomor 1 Tahun 1974;

2. Pasal 13 mengatur prosedur pemahaman dispensasi bagi anak yang belum mencapai usia minimum, yaitu :

a. Apabila seorang calon suami belum mencapai umur 19 tahun dan calon istri belum mencapai umur 16 tahun hendak melansungkan pernikahan, harus mendapat dispensasi dari Pengadilan Agama;

b. Pemohonan dispensasi nikah bagi mereka tersebut pada ayat (1) Pasal ini, diajukan oleh kedua orang tua pria ataupun wanita kepada Pengadilan Agama yang mewilayahi tempat tinggalnya;

c. Pengadilan Agama setelah memeriksa dalam persidangan dan berkeyakinan bahwa terdapat hal-hal yang memungkinkan untuk memberikan dispensasi tersebut, maka Pengadilan Agama memberikan dispensasi nikah dengan suatu penetapan;

d. Salinan penetapan itu dibuat dan diberikan kepada pemohon untuk memenuhi persyaratan melangsungkan pernikahan.

Permohonan dispensasi perkawinan terhadap seorang laki-laki dan perempuan yang akan melangsungkan perkawinan, namun belum mencapai umur sesuai dengan ketentuan Undang-Undang Nomor 1 Tahun 1974 Tentang Perkawinan tersebut sebagaimana disebutkan di atas, dimohonkan oleh orang tua kepada pengadilan.

Berdasarkan uraian diatas penulis tertarik merumuskan masalah sebagai berikut :

1. Apa sajakah dalil-dalil yang diajukan dalam permohonan dispensasi perkawinan di Pengadilan Agama Semarang?

2. Apa sajakah dasar pertimbangan hakim dalam memberikan dispensasi perkawinan di Pengadilan Agama Semarang?

3. Apakah implikasi dispensasi perkawinan di Pengadilan Agama Semarang terhadap eksistensi rumah tangga?

\section{B. METODE PENELITIAN}

Metode Penelitian yang digunakan dalam penelitian ini adalah metode yuridis sosiologis. Yuridis sosiologis, yaitu selain menggunakan asas dan prinsip hukum dalam meninjau, melihat, dan menganalisa masalah-masalah, penelitian ini meninjau bagaimana pelaksanaannya dalam praktek.

Spesifikasi penelitian yang digunakan adalah penelitian deskriptif analisis. Sesuai dengan 
namanya maka penelitian deskriptif analisis adalah suatu bentuk penelitian yang bertujuan untuk menggambarkan karakteristik dari objek yang diteliti kemudian dikaitkan dengan praktek pelaksanaan hukum positif yang menyangkut permasalahan yang diteliti

\section{HASIL PENELITIAN DAN PEMBAHASAN}

1. Dalil-dalil yang diajukan dalam permohonan dispensasi perkawinan di Pengadilan Agama Semarang.

Adapun dalil-dalil yang sering diajukan dalam permohonan dispensasi perkawinan di Pengadilan Agama Semarang adalah sebagai berikut:

a. Kekhawatiran orang tua karena pergaulan anak;

Pergaulan remaja yang semakin tidak mengenal batas karena pengaruh budaya asing yang negatif yang mengakibatkan fenomena perkawinan di bawah umur semakin meningkat. Padahal sudah disebutkan di dalam Pasal 7 ayat (1) UndangUndang Nomor 1 Tahun 1974 bahwa untuk melangsungkan perkawinan, maka pihak pria harus berusia 19 tahun dan wanita 16 tahun. Tetapi dalam kenyataannya di masyarakat, perkawinan dilangsungkan oleh orang yang belum berusia sebagaimana disebutkan dalam Pasal 7 ayat (1) Undang-Undang Nomor 1 Tahun 1974.

Pelaksanaan perkawinan di usia muda memang dilatarbelakangi sebab harus dilaksanakannya perkawinan tersebut. Memang ada pihak-pihak yang menginginkan perkawinan segera dilangsungkan untuk menghindari hal-hal negatif yang mungkin dapat terjadi terhadap anak-anak mereka, jika perkawinan tidak segera dilaksanakan.

b. Alasan kesehatan dan memperoleh keturunan;

Untuk alasan ini memang jarang diajukan, tetapi orang tua lebih berupaya untuk mencegah anak-anak mereka dari pergaulan bebas saat ini. Untuk alasan ini, Abdul Manan menyatakan bahwa :

Alasan mengapa perkawinan itu harus segera dilaksanakan, yakni untuk menjaga kelangsungan keturunan karena salah satu pihak menderita penyakit dan apabila perkawinan itu tidak segera dilaksanakan, maka kedua belah pihak tidak bisa memperoleh keturunan dari perkawinan tersebut, sehingga dalam pelaksanaan-nya perlu mendapatkan dukungan atau dispensasi dari berbagai pihak termasuk Pengadilan Agama. ${ }^{4}$

Budaya menikah muda di kalangan masyarakat saat ini semakin menjadi fenomena. Melihat artis muda di Indonesia, yang berani menikah di usia muda mendorong remaja untuk melakukan hal yang sama, dengan dalih agar tidak terjerumus pada pergaulan bebas dan zina. Mereka menikah hanya berdasarkan cinta, tidak melihat faktor lainnya yaitu ekonomi, kematangan fisik, dan emosional.

Bahkan ada pula yang berpendapat bahwa jika menikah muda, maka akan dapat melihat perkembangan anaknya hingga dewasa nanti, jika menikah muda maka bila anaknya sudah dewasa, orang tuanya akan masih terlihat muda, dan alasan-alasan lainnya. Perkawinan bukanlah perlombaan, siapa cepat maka dia yang menang, tetapi yang terpenting adalah kualitas dari rumah tangga hasil perkawinannya.

c. Ketakutan anak jika nanti tidak menikah, mengurangi beban orang tua;

Adapula orang tua yang takut jika anaknya akan menjadi perawan tua dan tidak laku jika umurnya nanti bertambah tua. Bagi beberapa

4 Abdul Manan, loc.cit. 
kalagan, dengan menikahkan anak perempuannya maka beban orang tua akan menjadi berkurang, karena anak akan menjadi tanggung jawab suaminya. Perkawinan juga dijadikan alat bagi beberapa pihak untuk dapat meningkatkan perekonomian keluarga, yakni dengan menikahkan anaknya dengan orang yang lebih mampu dari keluarganya.

Para orang tua sepertinya tidak mempedulikan beban mental anakanak mereka. Kesiapan mental sangat diperlukan bagi siapapun yang akan melangsungkan perkawinan. Karena dalam suatu perkawinan, maka mempelai akan dapat mengetahui karakter maupun sifat asli dari pasangannya yang sebelumnya tidak diketahuinya. Jika mereka dapat menerima kelebihan dan kekurangan masing-masing, maka hal itu tidak akan menjadi masalah, tetapi jika tidak dapat menerimanya hanya akan menimbulkan permasalahan seperti pertengkaran yang terus-menerus, yang dapat menjadi sebab terjadinya perceraian.

d. Karena hamil di luar nikah;

Hamil di luar nikah ini yang sekarang banyak terjadi di kalangan remaja, tentunya akibat pergaulan bebas. Orang tua akan sangat malu jika anaknya hamil sebelum adanya perkawinan. Oleh karena itu, orang tua mengajukan dispensasi agar si anak dapat melangsungkan perkawinan meskipun belum cukup umur untuk melakukan perkawinan.

Persoalan hamil di luar nikah ini merupakan permasalahan yang sangat besar tidak hanya bagi keluarga pihak perempuan tetapi juga negara. Jika hal tersebut terus dibiarkan, maka moral bangsa akan menjadi semakin rusak.

Anak remaja zaman sekarang sangat sulit dikontrol. Pengaruh kemajuan teknologi yang ikut serta membuat remaja saat ini semakin tidak mengenal peraturan. Budaya luar yang tidak baik, banyak yang dicontoh, seperti pergaulan bebas.

e. Kekhawatiran orang tua jika si anak melanggar hukum dan agama;

Orang tua akan sangat merasa khawatir jika anak sudah mulai menyukai lawan jenis. Hubungan antara lawan jenis memang hal yang normal, tetapi jika tidak mengingat aturan dan norma agama dikhawatirkan hal-hal yang tidak baik akan terjadi, seperti hamil di luar nikah yang akan mencoreng nama baik keluarga.

Dengan berbagai alasan di atas, orang tua menikahkan anaknya yang sebenarnya belum siap secara lahir dan batin membentuk rumah tangga karena umur yang masih muda.

Dengan alasan tertentu, pemohon mengajukan permohonan dispensasi perkawinan, tetapi tidak lantas hakim dapat mengabulkan permohonan tersebut. Hakim mempunyai kebebasan dan otoritas untuk memutuskan akan memberikan dispensasi atau tidak. Hakim juga memberikan nasehat bagi para pihak sebelum proses sidang dilanjutkan. ${ }^{5}$ Jika terjadi perceraian, dan perkawinan yang dilangsungkan masih "seumur jagung", itupun juga membawa dampak yang tidak baik bagi kedua mempelai. Misalnya perkawinan itu hanya dianggap sebagai permainan atau menutupi aib, anak perempuan akan menjadi janda jika terjadi perceraian, dan lain sebagainya.

Implikasi dari diajukannya permohonan dispensasi perkawinan tersebut, maka calon mempelai dipaksa untuk dapat berumah tangga dengan baik. Melihat kondisi calon

5 Wawancara dengan Bapak Drs. Zaenal Arifin, S.H., M.H. selaku Hakim Pengadilan Agama Semarang, pada tanggal 13 Maret 2014. 
mempelai dari segi emosional, fisik, ekonomi, dan dari segi lainnya yang belum mapan, maka orang tua harus ikut campur dalam urusan rumah tangga calon mempelai nantinya. Orang tua akan menjadi pengawas terhadap rumah tangga anak-anaknya. ${ }^{6}$

2. Dasar pertimbangan hakim dalam memberikan dispensasi perkawinan di Pengadilan Agama Semarang.

Dasar pertimbangan hakim dalam pemberian dispensasi perkawinan bagi pihak mempelai yang belum mencukupi batas umur perkawinan adalah karena pertimbangan kemaslahatan, yakni apabila tidak segera dilangsungkan pernikahan terhadap calon mempelai tersebut, maka akan dikhawatirkan terjadi perbuatan-perbuatan yang melanggar norma agama dan peraturan yang berlaku. Ketakutan pihak keluarga terutama karena pergaulan remaja saat ini yang sudah terlalu bebas, sehingga dikhawatirkan akan mencoreng nama baik keluarga, sehingga diharapkan dengan memberikan dispensasi perkawinan maka akan mendapatkan banyak manfaat.

Dasar pertimbangan hakim Pengadilan Agama Semarang yang digunakan untuk mengabulkan dispensasi usia perkawinan adalah : ${ }^{7}$

(1) Ketentuan Pasal 7 ayat (2) UndangUndang Nomor 1 Tahun 1974;

(2) Ada larangan perkawinan atau tidak; Dalam Undang-Undang Nomor 1 Tahun 1974 disebutkan perkawinan yang dilakukan tidak melanggar laranglarangan perkawinan, yaitu dilakukan antara 2 (dua) orang yang mempunyai

(a) Hubungan darah dalam garis keturunan lurus ke bawah ataupun ke atas;

(b) Hubungandarah dalamgarisketurunan ke samping, yaitu antara saudara,

6 Wawancara dengan Bapak Drs. Zaenal Arifin, S.H., M.H. selaku Hakim Pengadilan Agama Semarang, pada tanggal 13 Maret 2014.

7 Wawancara dengan Bapak Drs. Zaenal Arifin, S.H., M.H. selaku Hakim Pengadilan Agama Semarang, pada tanggal 13 Maret 2014. antara saudara dengan saudara orang tua, dan antara seseorang dengan saudara neneknya;

(c) Hubungan semenda, yaitu mertua, anak tiri, menantu dengan ibu/bapak tiri;

(d) Hubungan susuan, yaitu orang tua susuan dan bibi/paman susuan;

(e) Hubungan saudara dengan istri (ipar) atau sebagai bibi atau keponakan dari istri, dalam hal seorang suami beristri lebih dari satu orang;

(f) Hubungan yang oleh agamanya atau peraturan lain yang berlaku larangan untuk melakukan perkawinan.

Dalam KHI juga melarang melangsungkan perkawinan antara seorang pria dengan seorang wanita yang disebabkan karena hal-hal yang disebutkan dalam Pasal 39 sampai Pasal 44.

a. Pasal 39

Dilarang melangsungkan perkawinan antara seorang pria dengan seorang wanita disebabkan :

1) Karena pertalian nasab :

a) Dengan seorang wanita yang melahirkan atau yang menurunkannya atau keturunannya;

b) Dengan seorang wanita keturunan ayah atau ibu;

c) Dengan seorang wanita saudara yang melahirkannya.

2) Karena pertalian kerabat semenda:

a) Dengan seorang wanita yang melahirkan istrinya atau bekas istrinya;

b) Dengan seorang wanita bekas istri orang yang menurunkannya;

c) Dengan seorang wanita keturunan istri atau bekas istri, kecuali putusnya hubungan perkawinan dengan bekas istrinya itu qobla al dukhul;

d) Dengan seorang wanita bekas istri keturunannya. 
3) Karena pertalian sesusuan :

a) Dengan wanita yang menyusuinya dan seterusnya menurut garis lurus ke atas;

b) Dengan seorang wanita sesusuan dan seterusnya menurut garis lurus ke bawah;

c) Dengan seorang wanita saudara sesusuan, dan kemenakan sesusuan ke bawah;

d) Dengan seorang wanita bibi sesusuan dan nenek bibi sesusuan ke atas;

e) Dengananakyang disusuioleh istrinya dan keturunannya.

b. Pasal 40

Dilarang melangsungkan perkawinan antara seorang pria dengan wanita karena keadaan tertentu :

1) Karena wanita yang bersangkutan masih terikat satu perkawinan dengan pria lain;

2) Seorang wanita yang masih berada dalam masa iddah dengan pria lain;

3) Seorang wanita yang tidak beragama Islam.

c. Pasal 41

(1) Seorang pria memadu istrinya dengan seorang wanita yang mempunyai hubungan pertalian nasab atau susuan dengan istri

a. Saudarakandung, seayahatau seibu serta keturunannya;

b. Wanita dengan bibinya atau kemenakannya.

(2) Larangan tersebut pada ayat (1) tetap berlaku meskipun istri-istri telah ditalak raj'i tetapi masih dalam masa iddah.

d. Pasal 42

Seorang pria dilarang melangsungkan perkawinan dengan seorang wanita apabila pria tersebut sedang mempunyai 4 (empat) orang istri yang keempat-empatnya masih terikat tali perkawinan atau masih dalam masa iddah raj'i atau pun salah seorang di antara mereka masih terikat perkawinan sedang yang lainnya dalam masa iddah talak raj'i.

e. Pasal 43

(1) Dilarang melangsungkan perkawinan antara seorang pria :

a. Dengan seorang wanita bekas istrinya yang ditalak tiga kali;

b. Dengan seorang wanita bekas istrinya yang dili'an.

(2) Larangan tersebut pada ayat (1) huruf a gugur, kalau bekas istri tadi telah kawin dengan pria lain, kemudian perkawinan tersebut putus ba'da dukhul dan telah habis masa iddahnya.

f. Pasal 44

Seorang wanita Islam dilarang melangsungkan perkawinan dengan seorang pria yang tidak beragama Islam.

\section{Implikasi dispensasi perkawinan di} Pengadilan Agama Semarang terhadap eksistensi rumah tangga.

Perkawinan bagi pihak yang masih belum mencapai batas umur perkawinan, dikarenakan kematangan psikis kedua belah pihak untuk mengarungi bahtera rumah tangga, bisa menjadi salah satu faktor penyebab perceraian. Belum dapatnya para pihak baik laki-laki dan perempuan untuk menyelesaikan permasalahan rumah tangga, selain itu faktor ekonomi juga turut menambah beban jika perkawinan tidak dipikirkan secara matang. Selain itu, implikasi dispensasi perkawinan bagi mempelai yang belum mencapai batas umur perkawinan dapat mengakibatkan kurang harmonisnya rumah tangga. Perkawinan bagi mereka yang belum mencapai batas umur perkawinan, dikhawatirkan akan menjadi boomerang bagi para pihak. Memang perkawinan akan menghalalkan hubungan antara pria dan wanita, tetapi jika mereka yang melakukan perkawinan hanya ditujukan untuk itu 
akan mengakibatkan permasalahan dikemudian hari.

Hal yang merupakan faktor penting dalam perkawinan adalah mempertahankan keutuhan rumah tangga. Perkawinan bukanlah suatu permainan, dan tidak untuk satu atau dua hari saja, tetapi seumur hidup yang harus dapat dipertanggungjawabkan di hadapan Allah S.W.T.

Cinta bukanlah satu-satunya dasar untuk dilakukannya perkawinan, tetapi juga harus berdasarkan aturan atau kaidah baik peraturan perundang-undangan dalam hal ini adalah Undang-Undang Nomor 1 Tahun 1974 dan ajaran agama, yakni Al Qur'an dan KHI, sehingga akan dapat tercipta keluarga yang sakinah, mawaddah, wa rahmah.

Untuk mencapai tujuan perkawinan, maka calon mempelai harus saling melengkapi, sehingga dapat tercapai kesejahteraan dan ketentraman hidup dalam rumah tangga. Perkawinan harus didasari dengan cinta dan bukanlah suatu paksaan karena perkawinan itu merupakan suatu perjanjian suci untuk membentuk keluarga bahagia dan kekal.

Melihat batasan umur yang sudah diatur dalam Undang-Undang Nomor 1 Tahun 1974 dan KHI, hal yang paling penting adalah kesiapan mental atau emosional kedua calon pasangan, yakni rasa tanggung jawab calon mempelai untuk menjalankan rumah tangganya. Bagi laki-laki mempunyai kewajiban untuk menafkahi keluarga, dan bagi perempuan harus mentaati suami dan siap menjadi ibu rumah tangga yang baik.

Kematangan emosional ini sangat penting artinya dalam menjaga keutuhan rumah tangga. Konflik dalam rumah tangga memang kadang terjadi, dan untuk menghadapinya harus dihadapi dengan kepala dingin. Jika tingkat kematangan emosional rendah, maka seseorang akan cenderung mengedepankan emosi tanpa berpikir mengenai upaya penyelesaiannya. Emosi yang meledak-ledak hanya akan menambah persoalan. Jika tingkat kematangan emosi seseorang tinggi, maka dia akan dapat berpikir dengan jernih tanpa mengedepankan emosi. Karena dalam sebuah rumah tangga, hanya ada satu nakhoda. Sangat sulit untuk menyatukan dua kepala tanpa ada rasa hormat dan tenggang rasa.

Sebagai perbuatan manusia dewasa, perkawinan merupakan peristiwa yang dapat berlangsung setelah melalui pertimbangan baik rasional maupun emosional atau mental. Selain dipikirkan dan diterima oleh akal sehat, semua persiapan perkawinan adalah persiapan mental dari calon pasangan itu sendiri. Persiapan mental ini dimulai dari hal yang paling sederhana, yaitu mengenal dan memahami pasangan serta memahami arti perkawinan. Dalam tahap persiapan perkawinan, membina hubungan sosial yang romantis dan harmonis merupakan hal yang penting dan perlu dijalani. ${ }^{8}$

Kurangnya pengetahuan tentang perkawinan dan rumah tangga bagi pasangan yang belum cukup umur juga penyebab timbulnya konflik dalam rumah tangga. Pengalaman mereka tentang hidup belum cukup memberikan pelajaran bagaimana seharusnya membentuk keluarga yang sejahtera dan harmonis. Karena proses mengenal yang sangat singkat dan hanya dikarenakan perasaan suka dan cinta, mereka hanya mengenal kebahagiaan sesaat. Bagaimana jika mereka merasa bosan, apakah akan meninggalkan pasangannya begitu saja. Pertengkaran-pertengkaran yang sering terjadi dan tidak mendapatkan solusi, akan mengakibatkan mereka merasa bosan dan jenuh. Untuk bercerai pun mereka harus memikirkannya lagi, karena usia yang masih muda dan stigma yang buruk dari masyarakat. ${ }^{9}$

8 Andi Sjamsu Alam, Usia Perkawinan Dalam Perspektif Filsafat Hukum dan Kontribusinya Bagi Pengembangan Hukum Perkawinan Indonesia, Ringkasan Disertasi, hlm. 7.

9 Wawancara dengan Bapak Drs. Zaenal Arifin,S.H., M.H, selaku Hakim Pengadilan Agama Semarang, pada tanggal 13 Maret 2014. 
Selain itu, implikasi perkawinan bagi mereka yang di bawah umur, terutama dilihat secara medis, pernikahan bagi mereka yang masih di bawah umur sangat berbahaya terutama bagi ibu muda yang mengandung dikhawatirkan rahimnya belum kuat untuk mengandung apalagi melahirkan, dan hal ini sangat berbahaya karena bisa menyebabkan kematian pada ibu ataupun bayi yang dilahirkan. ${ }^{10}$

Kenyataan di lapangan menunjukkan, bukannya melahirkan kemaslahatan keluarga dan rumah tangga, pernikahan di bawah umur justru banyak berujung pada perceraian. Di samping itu, ada dampak lain yang lebih luas, seperti meningkatnya angka kematian ibu saat hamil atau melahirkan lantaran masih berusia belia. ${ }^{11}$

Undang-undang juga mengkhawatirkan dalam hubungan dengan masalah kependudukan, karena alasan mengapa ditentukan umur minimal, terdapat kenyataan bahwa batas umur yang lebih rendah bagi seorang wanita untuk kawin, mengakibatkan laju kelahiran lebih tinggi jika dibandingkan dengan batas umur yang lebih tinggi. Memang pada waktu Undang-Undang Perkawinan dilahirkan, pelaksanaan program Keluarga Berencana (KB) belum seperti sekarang ini. Pada waktu itu orang berumah tangga masih mempunyai anak lebih dari tiga orang. Sehingga dikhawatirkan akan padat penduduk Indonesia jika kawin dengan umur yang sangat muda. ${ }^{12}$

Perkawinan yang dilakukan di usia yang relatif muda, di mana kondisi calon mempelai secara psikologis dan sosial belum matang, biasanya akan menimbulkan gejala-gejala psikologis dan sosial yang kurang baik. Apabila terjadi pertengkaran di antara keduanya, maka,

10 Wawancara dengan Bapak Drs. Zaenal Arifin,S.H., M.H, selaku Hakim Pengadilan Agama Semarang, pada tanggal 13 Maret 2014.

11 Wawancara dengan Bapak Drs. Zaenal Arifin,S.H., M.H, selaku Hakim Pengadilan Agama Semarang, pada tanggal 13 Maret 2014

12 Gatot Supramono, loc.cit. mereka tidak mampu menahan diri dari emosi, yang pada akhirnya mereka tidak mampu menjaga kelangsungan rumah tangga, yang berujung pada perceraian, sehingga harus ada pertimbangan khusus untuk itu daripada nantinya akan menjadi kemudharatan atau kerusakan.

Pertimbangan khusus tersebut salah satunya adalah umur calon mempelai yang sudah mencukupi untuk melangsungkan perkawinan. Karena pada dasarnya menghendaki adanya kebahagiaan dan kekal untuk selamanya. Perkawinan bukanlah tempat untuk mencoba-coba bagaimana membentuk sebuah rumah tangga. Janji suci perkawinan diucapkan tidak hanya disaksikan oleh manusia tetapi Allah S.W.T dan malaikat juga menjadi saksi atas ikatan janji suci tersebut.

Sebagaimana diketahui Allah S.W.T membenci adanya perceraian, meskipun perceraian itu tidak dilarang oleh agama. Tetapi perceraian akan menimbulkan akibat yang tidak baik terutama bagi anak-anak yang dilahirkan. Kekecewaan yang amat sangat akan dirasakan si anak jika perceraian terjadi di antara kedua orang tuanya, karena mereka tidak akan mendapatkan perhatian penuh dari kedua orang tuanya lagi.

Melihat implikasi dari perkawinan yang dilakukan oleh anak yang belum mencapai batas umur perkawinan, pemberian dispensasi perkawinan oleh hakim sangat berpengaruh terhadap perkembangan atas fenomena perkawinan di bawah umur. Hakim harus dapat menolak permohonan para pihak mengingat dampak perkawinan di bawah umur terutama terhadap eksistensi rumah tangga para pihak, meskipun para pihak tidak mau mengikuti nasehat hakim.

\section{PENUTUP}

\section{Kesimpulan}

a. Dalil-dalil yang diajukan dalam permohonan dispensasi perkawinan di Pengadilan Agama Semarang adalah calon istri telah hamil; 
b. Dasar pertimbangan hakim dalam memberikan dispensasi perkawinan di Pengadilan Agama Semarang adalah ketentuan Pasal 7 ayat (2) Undang-Undang Nomor 1 Tahun 1974.

c. Implikasi dispensasi perkawinan di Pengadilan Agama Semarang terhadap eksistensi rumah tangga adalah perkawinan dan rumah tangga bagi pasangan yang belum cukup umur juga penyebab timbulnya konflik dalam rumah tangga yang berujung pada perceraian.

\section{Saran}

a. Bagi hakim harus berani memberikan penolakan untuk pemberian dispensasi perkawinan kecuali terhadap Pemohon dispensasi yang telah hamil duluan, meskipun syarat-syarat telah dipenuhi oleh pihak pemohon. Hakim cukup memberikan nasehat - nasehat baik kepada para Pemohon dan para orang tua masing-masing, mengingat perkawinan di bawah umur memberikan dampak yang tidak baik bagi eksistensi rumah tangga calon mempelai nantinya;

b. Perlu adanya sosialisasi terhadap dampak dari adanya perkawinan di bawah umur bagi orang tua dan remaja pada umumnya, sehingga permohonan dispensasi perkawinan dapat ditekan.

c. Bagi masyarakat pada umumnya, yakni orang tua dan anak remaja perlu mendapat adanya sosialisasi penyuluhan hukum dari pemerintahan daerah setempat mengenai dampak dari adanya perkawinan di bawah umur, sehingga permohonan dispensasi perkawinan dapat ditekan.

\section{DAFTAR PUSTAKA}

\section{- Buku-buku:}

Ahmad Azhari Basyir, 1999, Hukum Perkawinan Islam, UII Press, Yogyakarta.

Andi Sjamsu Alam, Usia Perkawinan Dalam Perspektif Filsafat Hukum dan Kontribusinya Bagi Pengembangan Hukum Perkawinan Indonesia, Ringkasan Disertasi,

Idris Ramulyo, 1996, Hukum Perkawinan Indonesia, Budi Aksara, Jakarta.

M.Yahya Harahap, 2005, Kedudukan Kewenangan dan Acara Peradilan Agama UndangUndang Nomor 7 Tahun 1989, Sinar Grafika, Jakarta.

Mahmud Yunus, 1964, Hukum Perkawinan Dalam Islam, Al Hidayah, Jakarta.

Marhainis Abdulhay, 1984, Hukum Perdata Material Jilid I, Pradnya Paramita, Jakarta.

Miftah Faridl, 1999, 150 Masalah Nikah Keluarga, Gema Insani, Jakarta.

Moh. Taufik Makarao, 2004, Pokok-pokok Hukum Acara Perdata, Cetakan I, Rineka Cipta, Jakarta. 